\title{
NILAI FILOSOFI JAWA DALAM SERAT CENTHINI
}

\author{
Sutrisna Wibawa \\ FBS Universitas Negeri Yogyakarta \\ email: trisnagb@uny.ac.id
}

\begin{abstract}
Abstrak
Penelitian ini bertujuan untuk menggali dan merumuskan nilai filosofi Jawa dan landasan filosofis dalam Serat Centhini. Metode yang digunakan metode deskriptif kualitatif. Sumber data penelitian adalah naskah Serat Centhini. Langkah-langkah penelitian meliputi pengumpulan data, reduksi data, klasifikasi data, pemaparan data, dan penarikan kesimpulan. Analisis data menggunakan metode hermeneutika dan heuristika. Hasil penelitian sebagai berikut. Pertama, nilai filosofi Jawa dalam Serat Centhini tergambar pada kandungan budaya dan filsafat Jawa yang menggambarkan keadaan masyarakat Jawa saat Serat Centhini ditulis. Filosofi Jawa dalam Serat Centhini tercermin dalam nilai kesempurnaan hidup (ngudi kasampurnan) dan filsafat asal dan arahnya yang ada (sangkan paraning dumadi). Kedua, filosofi Serat Centhini tercermin dalam landasan ontologis, epistemologis, dan aksiologis.
\end{abstract}

Kata kunci: filosofi Jawa, Serat Centhini, kesempurnaan hidup

\section{JAVANESE PHILOSOPHICAL VALUES IN SERAT CENTHINI}

\begin{abstract}
This study aims to reveal and formulate Javanese philosophical values and philosophical foundations in Serat Centhini. It was a qualitative descriptive study. The data source was the Serat Centhini text. The research steps included data collection, data reduction, data display, and conclusion drawing. The data were analyzed using the hermeneutic and heuristic techniques. The findings are as follows. First, Javanese philosophical values in Serat Centhini are reflected in Javanese cultural contents and philosophy reflecting the Javanese society when Serat Centhini was written. The Javanese philosophy in Serat Centhiniis reflected by the life perfection value (ngudi kasampurnan) and the philosophy of origin and destination (sangkan paraning dumadi). Second, the philosophy in Serat Centhini is reflected in the ontological, epistemological, and axiological foundations.
\end{abstract}

Keywords: Javanese philosophy, Serat Centhini, life perfection

\section{PENDAHULUAN}

Kehidupan di dunia dihadapkan pada berbagai pertanyaan dan persoalan. Hal itu wajar karena manusia selalu dihinggapi rasa keingintahuan. Driyarkara (2006: 999-1001) menyatakan bagaimana dari keinginan akan mengerti, akan kebenaran, timbul ilmu-ilmu pengetahuan, dan akhirnya muncullah filsafat. Filsafat itu timbul dari setiap orang, asal saja orang itu hidup sadar dan menggunakan pikirannya. Filsafat adalah bentuk ilmu pengetahuan tertentu, bahkan bentuk pengetahun manusia yang sempurna, yang merupakan perkembangan yang terakhir dari pengetahuan luar biasa. Filsafat dapat dipandang dari dua segi, filsafat sebagai ilmu pengetahuan dan filsafat dalam arti yang lebih luas, yaitu usaha mencari jawaban atas pertanyaan- 
pertanyaan hidup, menanyakan dan mempersoalkan segala sesuatu. Filsafat sebagai ilmu yang tersendiri itu tidak niscaya adanya; hal itu meminta tingkatan kebudayaan yang agak tinggi. Sebaliknya, menyangkut filsafat dalam arti yang lebih luas, dalam arti anasir-anasir filsafat dalam pikiran manusia, hal itu dapat dikatakan tentu ada, biarpun sedikit. Pada masyarakat yang tingkat kebudayaannya belum berkembang, dapat dijumpai pikiran-pikiran tentang sebab-akibat, pandangan-pandangan tentang manusia, Tuhan dan dunia, pendapat-pendapat tentang hidup, tentang perbuatan-perbuatan manusia atau etika, dan lain-lain. Filsafat adalah eksistensial sifatnya, erat hubungannya dengan hidup sehari-hari. Hidup sehari-hari memberikan bahan-bahan untuk direnungkan. Filsafat berdasarkan dan berpangkalan pada manusia yang konkrit pada diri manusia yang hidup di dunia dengan segala persoalan yang dihadapi. Filsafat adalah pernyataan dari sesuatu yang hidup di dalam hati setiap orang, maka walaupun tidak setiap orang dapat menjadi ahli filsafat, namun yang dibicarakan atau dipersoalkan dalam filsafat itu memang berarti bagi semua manusia.

Driyarkara (2006:1003) selanjutnya menyatakan setiap orang di dunia ini memuculkan berbagai pertanyaan, antara lain: manusia tentu mempersoalkan sangkan parannya, asal mula, dan tujuannya. Manusia akan bertanya pada diri sendiri: dari manakah manusia datang dan ke mana tujuannya, ke manakah arah hidupnya, apa artinya hidup, untuk apa manusia hidup, bagaimana setelah manusia meninggal, akan hapus sama sekali apa tidak? Manusia akan selalu bertanya demikian dan mencoba menemukan jawabannya. Filsafat mendorong usahausaha manusia untuk mencari jawaban atas berbagai pertanyaan tersebut. Suseno (1992:17) menyatakan berfilsafat bergulat dengan masalah-masalah dasar manusia.
Filsafat cenderung mempertanyakan apa saja secara kritis dari seluruh realitas kehidupan. Hakikatnya filsafat membantu masyarakat dalam memecahkan masalahmasalah kehidupan. Filsafat dapat dipandang sebagai usaha manusia untuk menangani pertanyaan-pertanyaan fundamental tersebut secara bertanggung jawab. Nasroen (1967:19) menyatakan falsafah itu adalah hasil dari tinjauan manusia tentang makna dirinya, makna alam, dan tujuan hidupnya dengan mempergunakan pikiran dan dibantu oleh rasa dan keyakinan yang ada dalam dirinya itu, sebagai suatu kesatuan, yang satu mempengaruhi dan membantu yang lain. Falsafah dijadikan pegangan dan pedoman dalam memberi isi hidupnya dan berusaha mencapai tujuan hidupnya (Suseno, 2005).

Driyarkara (2006:973-998) lebih lanjut menguraikan tentang filsafat. Kata filsafat dijabarkan dari perkataan philosophia. Perkataan itu berasal dari bahasa Yunani yang berarti cinta akan kebijaksanaan (love of wisdom). Pythagoras atau Sokrateslah yang pertama-tama menyebut diri Philosophus, pecinta kebijaksanaan, artinya orang yang ingin mempunyai pengetahuan yang luhur (sophia); mengingat keluhuran pengetahuan yang dikejarnya itu, maka orang tidak mau berkata bahwa telah mempunyai, memiliki, dan menguasainya. Filsafat menjadi suatu ajaran hidup. Orang mengharapkan dari filsafat dasar-dasar ilmiah yang dibutuhkan untuk hidup. Filsafat diharapkan memberikan petunjuk-petunjuk bagaimana kita harus hidup untuk menjadi manusia yang sempurna, yang baik, yang susila, dan bahagia. Jadi, tidak hanya ilmu yang teoretis saja, melainkan yang praktis juga, artinya yang mencoba menyusun aturanaturan yang harus dituruti agar hidup kita mendapat isi dan nilai. Dan ini sesuai dengan arti filsafat sebagai usaha mencari kebijaksanaan yang meliputi baik pengetahuan (insight) maupun sikap hidup yang benar-benar, yang sesuai dengan pengetahuan itu. 
Serat Centhini merupakan salah satu karya sastra terbesar dalam kebudayaan Jawa. Serat Centhini ditulis dalam bentuk tembang macapat, mulai ditulis pada tahun 1814 dan selesai pada tahun 1823. Atas kehendak Sunan Pakubuwana V, Serat Centhini ini dimanfaatkan untuk menghimpun segala macam pengetahuan kebudayaan Jawa lahir dan batin pada masa itu, termasuk di dalamnya keyakinan dan penghayatan mereka terhadap agama. Serat Centhini dianggap sebagai ensiklopedi mengenai dunia dalam masyarakat Jawa. Sebagaimana tercermin dalam bait-bait awal, serat ini ditulis memang dengan ambisi sebagai perangkum baboning pangawikan Jawi (induk pengetahuan Jawa). Serat Centhini meliputi beragam macam hal dalam alam pikiran masyarakat Jawa. R.M.Ng. Poerbacaraka dan Tardjan Hadijaya dalam buku Kapustakan Jawa menyatakan bahwa Serat Centhini memuat halhal yang amat berbagai-bagai macamnya (Poerbacaraka dan Hadijaya, 1957: 83).

Keluasan dan kedalaman substansi Serat Centhini sebagaimana dijelaskan di atas, menunjukkan bahwa Serat Centhini merupakan hasil kebudayaan Jawa yang mengandung ajaran yang dapat memberikan petunjuk-petunjuk bagaimana orang harus hidup untuk menjadi manusia yang baik, yang susila, dan bahagia. Dalam penelitian ini, Serat Centhini dikaji dari sudut pandang filsafat sebagai ajaran hidup. Secara khusus, penelitian ini bertujuan untuk menggali dan merumuskan nilai filosofi Jawa dan landasan filosofis Serat Centhini.

\section{METODE PENELITIAN}

Penelitian ini menggunakan metode deskriptif kualitatif. Materi atau bahan penelitian ini berupa bahan kepustakaan dengan sumber primer naskah Serat Centhini karya Sunan Pakubuwana V, yang terdiri dari duabelas jilid (jilid I sampai dengan jilid XII). Naskah Serat Centhini yang dijadikan materi penelitian ada tiga, yaitu (1) Serat Centhini JIlid I-XII Koleksi Balai Kajian Sejarah dan Nilai Tradisional Ditjen Kebudayaan, Kementerian Pendidikan dan Kebudayaan, (2) Serat Centhini Jilid I-XII yang telah dialihaksarakan oleh Kamajaya, diterbitkan oleh Yayasan Centhini Yogyakarta, (3) Serat Centhini Jilid I-XII yang telah disadur/ diterjemahkan oleh Tim Universitas Gadjah Mada, Serat Centhini jilid I-IV di bawah koordinator Daru Suprapto diterbitkan oleh Balai Pustaka dan Jilid V-XII di bawah koordinator Marsono diterbitkan oleh Gadjah Mada University Press. Langkah-langkah penelitian yang dilakukan adalah pengumpulan data, reduksi data, klasifikasi data, display data, dan penarikan kesimpulan. Analisis data menggunakan metode hermeneutika dan heuristika.

\section{HASIL DAN PEMBAHASAN Budaya dan Filosofi Jawa dalam Serat Centhini}

Kebudayaan adalah keseluruhan sistem gagasan, tindakan, dan hasil karya manusia dalam rangka kehidupan masyarakat yang dijadikan milik diri manusia dengan belajar (Koentjaraningrat,1979:193). Kebudayaan berasal dari kata Sansekerta buddhayah, yang merupakan bentuk jamak dari buddhi yang berarti budi atau akal. Dengan demikian kebudayaan dapat diartikan hal-hal yang bersangkutan dengan akal (Koentjaraningrat, 1979:195). Kusumohamidjojo (2009:149) memaknai kebudayaan dalam arti culture sebagai keseluruhan proses dialektik yang lahir dari kompleksitas pemikiran, jiwa, dan nurani yang diwujudkan sebagai kompleksitas perilaku dan karya manusia dalam bentuk materialisasi (things), gagasan (ideas) yang diadaptasi, diterapkan, distandarisasikan, dikembangkan, diteruskan melalui proses belajar, dan diadaptasikan dalam kehidupan bersama.

Sutrisno (2008:6-8), dengan bertitik tolak dari pengertian kebudayaan menurut Peursen, menyatakan bahwa kebudayaan 
dewasa ini difahami sebagai kegiatan produktif dan bukan produksinya. Kebudayaan bukanlah sesuatu yang beku dan jadi, melainkan sesuatu yang senantiasa dalam proses perubahan. Kehidupan sosial politik tidak dapat dianggap sekali jadi dan serba lengkap, melainkan berada dalam proses semakin memungkinkan hidup yang lebih manusiawi. Penemuan-penemuan teknologi dan ilmiah semakin memungkinkan manusia untuk hidup bebas di alam. Dengan konsep dinamis kebudayaan, makna kebudayaan lebih dapat difahami lebih tepat. Untuk konteks Indonesia, kebudayaan tidak semata-mata dipandang sebagai warisan leluhur, tetapi sesuatu yang sedang diciptakan sekarang ini lewat pembangunan nasional. Kebudayaan bukan hanya kenyataan masa lampau yang dibanggakan, melainkan juga keharusan masa depan yang disusun dalam sebuah strategi kebudayaan.

Menurut Peursen (1988:18), kebudayaan itu tergambar dalam tiga tahap, yaitu (1) tahap mitis, (2) tahap ontologis, dan (3) tahap fungsional. Tahap mitis adalah sikap manusia yang merasakan dirinya terkepung oleh kekuatan-kekuatan gaib di sekitarnya, yaitu kekuasaan dewa-dewa alam raya atau kekuasaan kesuburan, seperti dipentaskan dalam mitologi-mitologi yang dinamakan bangsa-bangsa primitif. Tahap ontologis yaitu sikap manusia yang tidak hidup lagi dalam kepungan kekuasaan mitis, melainkan yang secara bebas ingin meneliti segala hal ikhwal. Tahap fungsional ialah sikap dan alam pikiran yang makin nampak dalam manusia modern, manusia tidak begitu terpesona lagi oleh lingkungannya (sikap mitis), manusia tidak lagi dengan kepala dingin ambil jarak terhadap objek penyelidikannya (sikap ontologis).

Koentjaraningrat (1979:200-201) menyatakan bahwa kebudayaan itu ada tiga wujud, yaitu pertama, wujud kebudayaan sebagai suatu kompleks dari ide-ide, gagasan, nilai-nilai, norma-norma, peraturan dan sebagainya. Kedua, wujud kebudayaan sebagai suatu kompleks aktivitas serta tindakan berpola dari manusia dalam masyarakat. Ketiga, wujud kebudayaan sebagai benda-benda hasil karya manusia. Tentang unsur kebudayaan, berdasarkan unsur-unsur kebudayaan yang ditemukan pada semua bangsa di dunia, terdapat tujuh unsur kebudayaan, yaitu: (1) bahasa, (2) sistem pengetahuan, (2) organisasi sosial, (4) sistem peralatan hidup dan teknologi, (5) sistem mata pencaharian hidup, (6) sistem religi, dan (7) kesenian (Koentjaraningrat, 1979: 218).

Pengertian, wujud, dan unsur kebudayaan sebagaimana dikemukakan di atas, berlaku pula dalam kebudayaan Jawa. Kebudayaan Jawa didasarkan atas peta kewilayahan yang meliputi seluruh bagian tengah dan timur dari pulau Jawa, dengan pusat kebudayaan wilayah bekas kerajaaan Mataram sebelum terpecah pada tahun 1755, yaitu Yogyakarta dan Surakarta. Wujud dan unsur kebudayaan Jawa mewarnai nilai filosofis Serat Centhini. Dalam Serat Centhini dapat dijumpai tiga wujud kebudayaan Jawa, yaitu kompleksitas dari ide-ide, gagasan, nilainilai, norma-norma dan peraturan yang berlaku dalam kebudayaan Jawa, wujud kebudayaan sebagai suatu kompleksitas aktivitas serta tindakan berpola dari manusia dalam masyarakat Jawa, dan wujud kebudayaan sebagai benda-benda hasil karya manusia Jawa. Demikian pula, unsur kebudayaan Jawa dalam Serat Centhini mengandung tujuh unsur kebudayaan Jawa, yaitu bahasa Jawa, sistem pengetahuan Jawa, organisasi sosial Jawa, sistem peralatan hidup dan teknologi Jawa, sistem mata pencaharian hidup Jawa, sistem religi Jawa, dan kesenian Jawa pada yang menggambarkan kebudayaan Jawa saat Serat Centhini ditulis.

Selain wujud dan unsur kebudayaan yang dapat dilihat dalam kekhasan budaya Jawa, Kamajaya (2007: 84-85) menjelaskan 
bahwa kebudayaan Jawa adalah pancaran atau pangejawantahan budi manusia Jawa, yang merangkum kemauan, cita-cita, ide, maupun semangat dalam mencapai kesejahteraan, keselamatan, dan kebahagiaan lahir dan batin. Datangnya bangsa Hindu-Jawa dan dengan masuknya agama Islam dengan kebudayaannya, maka kebudayaan Jawa menjadi filsafat sinkretis yang menyatukan unsur-unsur pra-Hindu, Hindu-Jawa, dan Islam. Seperti dikatakan oleh Arif (2010:35), filsafat menempatkan kebudayaan pada aras metafisis yang merujuk pada penempatan nilai sebagai aspek formal intrinsik.

Selanjutnya tentang filsafat Jawa menurut Kusbandriyo (2007:13) dalam tulisannya Pokok-pokok Filsafat Jawa, filsafat Jawa dimaknai sebagai filsafat yang menekankan pentingnya kesempurnaan hidup. Manusia berfikir dan merenungi dirinya dalam rangka menemukan integritas dirinya dalam kaitan dengan Tuhan. Dimensi ini adalah karakteristik yang dominan dan tidak dapat dilepaskan dengan kecenderungan hidup manusia Jawa. Pemikiran-pemikiran Jawa merupakan suatu usaha untuk mencapai kesempurnaan hidup, oleh karena itu intuisi memegang peranan penting. Bagi filsafat Jawa, sebagaimana dikemukakan oleh Zoetmulder (Kusbandriyo, 2007:13), pengetahuan filsafat senantiasa hanya merupakan sarana untuk mencapai kesempurnaan, sehingga dapat dirumuskan bahwa filsafat berarti cinta kesempurnaan. Ciptoprawiro (1986:21) juga menyatakan berfilsafat dalam kebudayaan Jawa berarti ngudi kasampurnan. Manusia mencurahkan seluruh eksistensinya, baik jasmani maupun rohani, untuk mencapai tujuan itu. Berdasarkan rumusan bahwa berfilsafat dalam kebudayaan Jawa adalah ngudi kasampurnan, bahwa Serat Centhini terbentuk dari filsafat Jawa, karena itu di dalam Serat Centhini berisi ajaran-ajaran kesempurnaan hidup. Kamajaya (1996:1) juga menyatakan bahwa Serat Centhini me- muat kawruh Jawa. Kawruh Jawa bukanlah sekedar mengandung pengetahuan melainkan kebijakan atau kebijaksanaan dengan tujuan hakiki: keselamatan dan kesejahteraan lahir batin sesuai dengan sifat dan cita-cita yang terkandung di dalam kebudayaan Jawa. Serat Centhini juga memuat filsafat terutama yang berkaitan dengan agama Islam, yang terdapat dalam bagian-bagian wejangan dari para guru maupun ulama, khususnya wejangan Seh Amongraga pada jilid-6, 7, 10, dan 12.

Terkait dengan ngudi kasampurnan, Koesnoe (2007:55) menyatakan bahwa filsafat Jawa merupakan filsafat sangkan paraning dumadi (filsafat asal dan arahnya yang ada). Filsafat sangkan paraning dumadi adalah suatu ajaran yang menunjukkan ulah daya hidup yang dinamakan sukma, yang bergerak menuju dan bersatu dalam daya hidup yang diberi nama kesempurnaan. Sangkan paraning dumadi juga dimaknai suatu ajaran yang tempatnya tidak di dalam alam kawruh yang menangani kanoragan, melainkan menangani gerak rohani untuk menyatu di dalam arus kehidupan secara benar-benar hidup sebagai kenyataan hidup sejati.

Filosofi Jawa tentang kesempurnaan hidup atau ngudi kasampurnan dan asal dan arahnya yang ada atau ngelmu sangkan paraning dumadi dalam Serat Centhini tercermin melalui tokoh utama Seh Amongraga. Nilai filosofis kesempurnaan hidup antara lain ditunjukjan oleh Seh Amongraga saat berdiskusi dengan $\mathrm{Ki}$ Bayi Panurta. Serat Centhini jilid V, Seh Amongraga menjelaskan kepada Ki Bayi tentang ilmu jisim jriyah kariyah, yaitu ilmu yang ada dalam semuanya. Jisim itu ada di dalam oral. Segala makhluk hidup itu sesungguhnya tidak mempunyai kekuasaan, seperti sampah dalam lautan tidak mungkin berharap menyatu. Gusti tetaplah Gusti, hamba tetaplah hamba, tidak bisa saling berganti.

Manusia percaya bahwa Hyang Agung tanpa arah tanpa tempat, tanpa bau warna 
tanpa rasa. Tanpa tempat tetapi bertempat yang tidak diketahui. Itulah mukmin, berkumpulnya ada dan tiada. Seh Amongraga menjelaskan tentang "curiga manjing warangka" dan "warangka manjing curiga". Itu adalah perlambang suksma masuk ke badan dan badan masuk ke suksma, itu adalah kesejatian shalat. Pada saat takbiratul ihram, di situlah menyatunya sukma ke badan dan badan ke sukma. Saat itulah menyatunya kehendak. Sebagai pintu masuk ke hati sanubari, dibuka dengan ikhram, mirat, munajad, tubadil, lestari maksudnya. Sukma ke badan. Dalam hal masuknya badan ke sukma, yaitu apabila sudah khusni dalam ikramnya shalat. Kusta daim ismu alim, lestari masuknya badan ke sukma. Sukma sudah bisa dikuasai oleh karena badan dapat memenuhi tuntutan sukma.

Cahaya malaikat adalah sinar penglihatan sejati. Malaikat itu gaib, meliputi segala rupa. Hanya segala yang dihendakai dari Hyang Agung yang bersifat bijaksana saja yang dihendaki. Cahaya malaikat itu hidayah sejati. Tanda-tanda nabi adalah pada zat yang mengeluarkan keramat. Tanda-tanda mukmin ialah pada afngal yang mengeluarkan mangunah yang meliputi tiga tingkat. Raja zaman nabi, mendapat anugerah Hyang Agung cahaya nurbuat, mulia dunia akhirat. Raja zaman wali diberi anugrah Hyang Widi berupa wahyu cahaya hidayat, diberikan rahmat pada akhir. Raja zaman mukminun diberi anugrah Hyang Wahyu lailatul qadri. Kemukminan pasti diberikan rahmat keduniaan (Marsono-V, 2005: 135-137).

Nilai kesempunaan hidup yang lain tercermin dalam wejangan Seh Amongraga tentang sepuluh pedoman hidup yang menjadi patokan dalam kehidupan. Pertama, syahadat dalam kaitan ini adalah rusaknya ilmu kebenaran karena tindakannya tidak sesuai dengan Nabi dan agama Rasullulah. Kedua, takyun yaitu menyatakan bahwa hal-hal yang baiklah yang mendapat perhatian khusus. Ketiga, sebab kematian adalah bahwa asal kematian yang akan mendatangi kita adalah akhir dari asal dan tujuan. Keempat adalah iman, yaitu hanya penerimaannya artinya penerimaan kekal, tidak ada kekhawatiran hati, hanya memusatkan diri kepasa Tuhan. Kelima adalah pana, yaitu bersyukur kepada tauhid yang berarti tekad yang teguh. Keenam adalah amal, yaitu keikhlasan. Ketujuh adalah niat, yaitu kemauan yang tiada henti-hentinya. Kedelapan adalah shalat karena Allah, artinya disertai dengan Lah 'karena Allah' ialah tanpa rasa susah, karena yang menyebabkan rusaknya shalat adalah kesusahan hati. Kesembilan adalah surga, yaitu mengikuti ajaran dengan penuh keyakinan, artinya syariat, dalil, hadis, dan ijmak. Kesepuluh adalah neraka, yaitu tidak mengikuti rasul, artinya tidak menurut akhlak (MarsonoVII, 200: 84-85).

Filsafat Jawa tentang asal dan arahnya yang ada atau ngelmu sangkan paraning dumadi dalam Serat Centhini tercermin dalam wejangan Seh Amongraga tentang asal-usul manusia di dunia. Menurut Seh Amongraga manusia diciptakan di dunia ini harus tahu asalnya. Barang siapa tahu dirinya, sesungguhnya itu tahu Tuhan. Dalam kitab Ihya Ulumuddin dikatakan, hendaknya semua manusia berebut ilmu pengetahuan dan wajib untuk mengetahui diri dan mengenal Hyang Suksma. Diceriterakan dalam kitab Ajadulngibat, subkana wa tangala, Hyang Maha Suci menciptakan manusia, akhadiyat dan takyun, tiada beradab tempatnya, wujud warna, bau, dan rasa belum ada di tempatnya tetapi sudah pasti kehadiran-Nya, nukat dan gaib. Dalam 40 hari, gaibul guyub namanya, alamnya alam lahut, gelap tempatnya, gelap kalbunya. Hadir dalam waktu 40 hari lagi, wahdat kun diam sabda-Nya. Pusat kun dalam uluwiyah masih remang-remang, masih samar-samar dan tidak terang kalbunya. Selanjutnya, 40 ketiga wakidiyat kun ahya, artinya darah baru melekat di tempatnya, gaib uwiyah menunjukkan terangnya ka- 
lbu. Keempat, 40 hari selanjutnya adalah alam arwah dan daging barulah melekat. Selanjutnya 40 hari lagi adalah alam ajesan, sudah berwujud tetapi belum jelas. Empat puluh hari yang keenam adalah alam mitsal, saat itulah sudah mulai jelas seluruh tubuhnya, pria wanitanya, namun berhakikat sama. Empat puluh hari yang ke tujuh adalah alam insan kamil, martabat manusianya sudah sempurna dan sudah berpisah jaraknya. Setelah yang sembilan bulan sepuluh hari, sudah jadilah syarat dan sifat manusianya, kemudian ditulislah batas usianya, keuntungan dan kemalangannya, kaya miskin, besar kecil, tinggi pendek, mulus cacat, jelek baik, sudah ada di dalam duryat kebahagiaan dari kodrat Illahi. Setiap manusia ditunggui malaikat yang diberi tugas menunggui di dalam tubuh manusia sampai lahir di dunia. Setelah lahir, manusia dikaruniai alat ucap dan pendengar, penglihat dan pencium, dan dilengkapi pula dengan budi pekerti. Manusia diciptakan melebihi sesamanya, yaitu semua yang diciptakan di dunia. Maka, hendaklah manusia bersyukur kepada Hyang Widi. Hanya manusialah yang banyak kenikmatannya. Oleh karena itu, sebagai manusia harus bertabiat yang baik. Menurut dalil, jangan lalai dalam pengetahuan, jika lalai sesatlah yang akan ditemui (Marsono-VII, 2005: 93-96).

\section{Landasan Filosofis Serat Centhini}

Sebagaimana dijelaskan pada bagian sebelumnya, Serat Centhini merupakan salah satu karya sastra terbesar dalam kesusastraan Jawa Baru yang menghimpun segala macam ilmu pengetahuan dan kebudayaan Jawa. Serat Centhini dianggap sebagai ensiklopedi mengenai dunia dalam masyarakat Jawa. Dilihat dari ilmu filsafat, kelengkapan dan kedalaman isi Serat Centhini menggambarkan adanya tiga landasan filosofis, yaitu landasan ontologis, epistemologis, dan aksiologis.

\section{Ontolologi Serat Centhini}

Ontologi merupakan bagian dari filsafat yang paling umum. Ontologi merupakan metafisika umum, yang mempersoalkan adanya segala sesuatu yang ada. Driyarkara (2006: 1020) menyatakan bahwa ontologi berbicara tentang ada: metafisika atau ontology yang membahas apakah arti ada itu, apakah kesempurnaannya, apakah tujuan, apakah sebab dan akibat, apa yang merupakan dasar yang terdalam dalam setiap barang yang ada. Bakker (1992:6) menyatakan bahwa ontologi berhubungan dengan ada dan yang ada. Bakker (1992:16) selanjutnya menjelaskan filsafat tentang ta meta ta physika yang menurut Aristoteles berpusat pada to on hei on, artinya pengada sekedar pengada (a being as being). Kata Yunani on merupakan bentuk netral dari oon dengan bentuk genetifnya ontos. Kata itu adalah bentuk partisipatif dari kata kerja einai (ada atau mengada), jadi berarti yang ada atau pengada. Arti kata mengada sebagai objek pemikiran, filsafat pertama sebagai ontologi diakui sebagai ilmu paling universal. Objeknya meliputi segala-galanya dengan seada-adanya. Maka einai dan to on lambat laun tidak hanya berarti ada atau tidaknya, melainkan segala-galanya menurut segala bagiannya dan menurut segala aspeknya. Kattsoff (2004:73-74) menjelaskan bahwa ontologi membicarakan asas-asas rasional dari yang ada. Ontologi berusaha untuk mengetahui esensi terdalam dari yang ada. Apakah kenyataan itu mengandung tujuan atau bersifat mekanis, ini merupakan pertanyaan ontologi. Menurut Kattsoff (2004:4748) sesuatu apapun haknya bersifat yang ada atau singkatnya barang sesuatu itu ada.

Hasil penelitian menunjukkan bahwa ontologi dalam Serat Centhini berangkat dari kenyataan yang sungguh-sungguh ada. Hal itu dapat dilihat dari awal tujuan penulisan Serat Centhini. Dalam Serat Centhini jilid satu, disebutkan putera mah- 
kota kerajaan Surakarta Kanjeng Pangeran Adipati Anom Amengkunegara III memberi perintah kepada juru tulis Sutrasna, untuk memaparkan segala pengetahuan Jawa yang dapat digunakan sebagai induk (babon) semua pengetahuan Jawa (pangawikan Jawi) dalam gubahan cerita yang dituangkan dalam bentuk tembang, agar tidak menjemukan tetapi menyenangkan pendengar, seperti dalam teks tembang berikut ini:

Sri narpadmaja sudigbya, talatahing nuswa Jawi, Surakarta Adiningrat, agnya ring kang wadu carik, Sutrasna kang kinanthi, mangun reh cariteng dangu, sanggyaning kawruh Jawa, ingimpun tumrap kakawin, mrih tan kemba karya dhangan kang miyarsa.

Lejere kanang carita, laksananing Jayengresmi, ya Seh adi Amongraga, atmajeng Jeng Sunan Giri, kontap janma linuwih, oliya wali majedub, paparenganing jaman, Jeng Sultan Agung Mentawis, tinengeran srat kang susuluk Tambangraras.

Karsaning kang narputra, baboning pangawikan Jawi, jinereng dadya carita, sampating karsa marengi, nemlikur Sabtu Pahing, lek Mukaram wewarseku, Mrakeh Hyang Surenggana, Bathara Yama dewa ri, Amawulu Wogan Suajang sumengka.

Pancasudaning satriya, wibawa lakuning geni, windu Adi Mangsa Sapta, sangkala angkaning warsi. Paksa suci sabda ji, rikang pinurwa ing kidung, duk kraton Majalengka, Sri Brawijaya mungkasi, wonten maolana sangking nagri Juddah.

Terjemahan bebas sebagai berikut:

Putera mahkota kerajaan Surakarta Adiningrat di wilayah Jawa, memerintahkan kepada juru tulis, Sutrasna, untuk menggubah sebuah cerita, yang berisi segenap penhetahuan Jawa, yang dihimpun dalam tembang, agar menyenangkankan yang mendengar.

Pokok cerita tentang perjalnan Jayengresmi, ya Seh Amongraga, putera Sunan Giri, yang termasyur sebagai wali, di jaman Sultan Agung Mataram, yang diberi judul Suluk Tambangraras.

Kehendak sang putera mahkota, menjadi induk pengethuan Jawa, diuraikan dalam bentuk ceritera, penulisan dimulai hari Sabtu Pahing, tanggal dua puluh enam tahun Mukharam, wuku Marakeh, dewa Hyang Surenggana, padewan Batahara Yama, paringkelan mawalu, pandangon wogan.

Pancasuda satriya wibawa jalannya api, windu Adi, mangsa tujuh, sangkala angka tahun 1724, ketika memulai menulis tembang, jaman karaton Majalengka, raja terakhir Brawijaya, ada maulana dari Jeddah.

Berdasarkan empat bait tembang tersebut, jelas bahwa apa yang diuraikan dalam Serat Centhini berangkat dari sesuatu yang ada, yaitu segala pengetahuan Jawa yang lengkap dan menyeluruh. Darusuprapto (1991:3) dalam saduran Serat Centhini jilid satu, menyebutkan jenis pengetahuan Jawa antara lain mengenai hal ikwal yang bertalian dengan agama, mengenai beraneka ilmu: kebatinan, kekebalan, perkerisan, perumahan, dan pertanian; berbagai kesenian: kesusasteraan, karawitan, dan tari; bermacam primbon: perhitungan baik buruk hari atau waktu berjampi-jampi; berbagai jenis masakan makanan; adat istiadat dan cerita yang bertalian dengan peninggalan bangunan kuna setempat, dan sebagainya. "Mengingat luasnya pengalaman jasmani dan rohani yang dipaparkan dalam Serat Centhini, sudah pantas kita menyebutnya sebagai ensiklopedi kebudayaan Jawa, yang sebagian besar 
mengandung kenyataan yang masih terdapat pada masyarakat Jawa dewasa ini" (Darusuprapto, 1991:v). Apa yang tertulis dalam Serat Centhini merupakan realitas kehidupan masyarakat pada saat Serat Centhini itu ditulis, yaitu sekitar tahun 1814 Masehi. Serat Centhini merupakan bagian dari karya sastra yang menggambarkan realitas kehidupan masyarakat. Sebagaimana dikemukakan Wellek dan Warren (1989:109) bahwa sastra menyajikan kehidupan, dan kehidupan sebagian besar terdiri dari kenyataan sosial, walaupun karya sastra juga meniru alam dan dunia subjektif manusia.

Realitas kehidupan masyarakat yang berupa konsepsi kehidupan masyarakat yang berkembang dan digunakan oleh masyarakat pada saat Serat Centhini ditulis. Serat Centhini ditulis dengan cara mengumpulkan data langsung dari seluruh wilayah Jawa, mulai dari Jawa Timur, Jawa Tengah, sampai Jawa Barat, bahkan untuk pengetahuan agama Islam terlebih dahulu menugasi anggota penulis untuk naik haji. Tugas ketiga pujangga adalah R.Ng. Ranggasutrasna bertugas menjelajahi pulau Jawa bagian timur dari Surakarta melalui Jawa Tengah bagian utara ke Banyuwangi, kembalinya lewat bagian selatan, R.Ng. Yasadipura II bertugas menjelajahi Jawa Tengah sebelah utara, melalui Surakarta sampai Anyer, Banten, berangkat lewat Jawa Tengah utara, kembalinya lewat bagian selatan, dan R.Ng. Sastradipura bertugas menguraikan segala sesuatu soal ilmu agama Islam, terutama ilmu Tasawuf. Tugas para pujangga itu untuk melihat, mendengarkan, menyelidiki, mendalami, dan mencatat segala sesuatu yang dijumpai dalam penjelajahannya (Kamajaya, 1996:4-5).

Contoh pengetahuan tentang yang ada yang digunakan sebagai pedoman masyarakat pada masa itu adalah konsepsi pengetahuan memilih jodoh yang diuraikan Ki Ajar Sutikna kepada Cebolang, sebagaimana disebutkan pada pupuh 187, bait 30-32, kata Ki Ajar, "Jika kamu akan memilih wanita yang baik, pantas dijadikan istri, silakan merenungkan makna kata-kata bobot, bebet, dan bibit. Kata bobot bermaksud hendaknya memilih wanita sejati, yang dilihat dari silsilah keturunan ayahnya, ada tujuh macam dan salah satu dapat menjadi syarat pilihan. Selanjutnya dijelaskan pada pupuh 188, bait 1 sampai dengan 44 ada tujuh macam, yaitu: (1) berdarah bangsawan, keturunan para raja Jawa yang sewaktu hidup mempunyai kedudukan tinggi, (2) keturunan orang beragama, keturunan para ulama yang ahli kitab dan maknanya, (3) keturunan pertapa, keturunan para pendeta yang melakukan tapa, (4) keturunan sujana atau orang baik, keturunan orang yang berulah ilmu budaya, ketajaman rasa, dan kebijaksanaan, (5) keturunan orang pandai, orang yang pintar dalam segala pekerjaan, berulah kecekatan dan keterampilan, (6) keturunan perwira, keturunan prajurit yang mahir berperang dan terkenal keberaniannya, dan (7) keturunan orang supatya, keturunan petani yang rajin, tangguh, dan patuh. Kata bebet yaitu syarat bagi orang tua wanita, hendaknya dipilih orang supadya, yaitu orang yang banyak harta benda dan selalu mau memberi dana kepada orang miskin serta orang yang banyak beruntung sepanjang hidupnya. Kata bibit, yaitu syarat bagi wanita yang baik dijadikan istri. Hendaknya dipilih wanita yang baik parasnya dan banyak kepandaiannya. Ada 21 macam, yaitu (1) wanita bongoh tampak indah menyenangkan, tubuh wanita itu berseri, gemuk lagi kuat. Orang yang memperistri merasa puas. Wanita yang berciri demikian biasanya bijaksana, dapat membuka keinginan untuk bercinta, (2) sengoh, berkulit kuning, banyak senyum memberahikan. Wajah wanita itu berseri agak gemuk. Orang yang memperistri merasa sedap dan senang memandangnya, (3) plongeh, senyum, wanita itu tampak agak banyak tersenyum. Wanita yang berciri demikian 
berwatak setia dan rela, tingkah lakunya menarik hati, bersahaja sikapnya, wanita yang demikian mempesona, orang yang menghadapinya kagum memandangnya, (4) ndemenakake, menyenangkan. Sinar muka, sinar mata dan tutur katanya mengenakkan hati. Orang yang memperistri akan tertarik hatinya. Penampilan dan tingkah lakunya tidak angkuh. Wanita yang demikian membuka hati dalam bercinta, (5) sumeh, manis sering tertawa, pancaran wajahnya berhati sabar. Wanita yang demikian membangkitkan rayuan, (6) manis, manis air muka dan kocak matanya membuat orang terpesona karena mengandung perbawa, (7) merakati, menarik hati. Pandangan mata dan lafal bicara menarik hati. Orang yang memperistri senang karena daya rahasia yang tersembunyi. Wanita yang demikian dapat membangkitkan orang memandang dan mendengar bicaranya, (8) jatmika, sopan santun. Orang yang memperistri menjadi tenang, jernih pikiran dan dapat membuka jalan penalaran yang benar, (9) susila, berbudi baik. Sikap bicara dan pandangan mata, tingkah laku, berbudi baik, dan serba ikhlas, (10) kewes, terampil bicara. Roman muka manis, sikap tegas dan tajam pandangannya, membuat tertarik bagi yang diajak bicara, (11) luwes, bila berbicara fasih dan lentur gerak-gerik anggota tubuhnya, (12) gandhes, tutur kata dan tingkah lakunya menarik hati. Wanita yang demikian membangkitkan rasa senang, (13) dhemes, tenang sikap dan tutur katanya, serta sopan tingkah lakunya. Wanita yang demikian membangkitkan rasa senang, (14) sedhet, bentuk dan tinggi wanita itu sedang, cekatan bertingkah dan tidak tercela, (15) bentrok, wanita itu bertubuh besar, tinggi dan berisi, tampak serba seimbang, (16) lencir, wanita yang bertubuh tinggi semampai menarik hati, anggota tubuh bulat berisi, (17) wire, ialah wanita yang bertubuh kecil serasi, anggota tubuh ketat dan tidak bercacat, (18) gendruk, wanita yang bertubuh besar, seimbang, tetapi agak kendor, (19) sarenteg, wanita yang bertubuh agak tinggi dibanding dengan besar tubuhnya. Anggota tubuh berisi, gemuk buah dadanya, (20) lenjang, wanita yang bertubuh agak kecil, tetapi tinggi, dan (21) rangkung, wanita bertubuh besar, kurang tinggi, agak kerempeng (Darusuprapto, 1994:53-55).

Serat Centhini dilihat dari kuantitas kenyataan termasuk bagian dari monisme, yang menurut Bakker (1992:30), dalam pandangan filsafat Jawa, semua berada dalam kesatuan dengan Tuhan, entah itu tata alam, langit, atau Dewa. Kesatuan itu masih sementara di dunia, tetapi permanen di akhirat, jumbuhing atau pamoring kawula-Gusti adalah surga. Penjelasan tentang manusia dan Tuhan terdapat pada wejangan Seh Amongraga tentang zat, sifat, asma, dan af al, serta wujud, ilmu, nur, dan suhud. Zat itu satu tidak mungkin mendua. Sifat tentang keindahannya yang tidak mungkin dibandingkan. Asma ialah abadi, sedangkan af al itu pasti. Wujud adalah adanya kita ini dan adanya Tuhan. Ilmu ialah ilmu yang sesungguhnya tahu tentang sifat Tuhan. Nur adalah hidup kita karena asma Allah. Suhud adalah kenyataan kematian manusia karena af al Allah. Wujud manusia adalah zat Allah, ilmu manusia sifat Allah, nur manusia asma Allah, dan suhud manusia af al Allah (Marsono-VI, 2005: 116-118).

\section{Epistemologi Serat Centhini}

Epistemologi merupakan bagian atau cabang filsafat. Driyarkara (2006:1019) menjelaskan salah satu cabang filsafat tentang pengetahuan adalah logika yang memuat logika formal yang mempelajari asas-asas atau hukum-hukum memikir, yang harus ditaati supaya dapat berfikir dengan benar dan mencapai kebenaran serta logika material atau kritika (epistemology) yang memandang isi pengetahuan, bagaimana isi ini dapat dipertanggungjawabkan, mempelajari sumber-sum- 
ber dan asal ilmu pengetahuan, alat-alat pengetahuan, proses terjadinya pengetahuan, kemungkinan-kemungkinan dan batas pengetahuan, kebenaran dan kekeliruan, metode ilmu pengetahuan, dan lain-lain. Dalam pengantar saduran buku Epistemologi Filsafat Pengetahuan, Hardono (1994:5) mendefinisikan epistemologi atau filsafat pengetahuan adalah cabang filsafat yang mempelajari dan mencoba menentukan kodrat dan skope pengetahuan, pengandaian-pengandaian dan dasarnya, serta pertanggungjawaban atas pernyataan mengenai pengetahuan yang dimiliki. Filsafat pengetahuan menurut Gallagher (1994:180) merupakan usaha untuk membiarkan pikiran untuk mencapai pengenalan akan esensinya sendiri; usaha pikiran untuk mengekspresikan dan menunjukkan kepada dirinya sendiri dasar-asar kepastian yang kokoh. Pengetahuan dikaitkan dengan ekspresi mengetahui bukan hanya mengalami, tetapi mengekspresikan pengalamannya sendiri bagi dirinya sendiri. Mudhofir (1996:66) menjelaskan epistemologi yang juga disebut teori pengetahuan, secara etimologi berasal dari kata Yunani episteme yang artinya pengetahuan dan logos yang artinya teori. Epistemologi dapat didefinisikan sebagai cabang filsafat yang mempelajari asal mula atau sumber, struktur, metode, dan sahnya (validitas) pengetahuan. Pranarka (1979:16) menjelaskan pengetahuan adalah suatu daya yang fungsional di dalam hidup manusia. Dengan pengetahuan itu, manusia mengenali peristiwa dan permasalahan, menganalisis, mengurai, mengadakan interpretasi, dan menentukan pilihan-pilihan.

Kattsoff (2004:74) menjelaskan epistemologi ialah cabang filsafat yang menyelidiki asal-mula, susunan, metode-metode, dan sahnya pengetahuan. Kattsoff menyebutkaan metode-metode untuk memperoleh pengetahuan, yaitu (1) empirisme, (2) rasionalisme, (3) fenomenalisme ajaran Kant, (4) intuisionisme, dan (5) metode ilmiah. Empirisme adalah metode untuk memperoleh pengetahuan melalui pengalaman. Para penganut empirisme, mengatakan bahwa pengetahuan diperoleh dengan perantaraan indera. Rasionalisme berpendirian bahwa sumber pengetahuan terletak pada akal. Pengalaman dipandang sebagai sejenis perangsang bagi pikiran. Para penganut rasionalisme mengatakan bahwa kebenaran dan kesesatan terletak di dalam ide, dan bukannya dalam barang. Fenomenalisme Kant muncul setelah adanya kritik-kritik terhadap sudut pandang yang bersifat empiris dan yang bersifat rasional. Cara memperoleh pengetahuan menurut fenomenalisme Kant tergantung pada macam pengetahuan. Kant membedakan empat macam, yaitu yang analitis apriori, yang sintetis apriori, yang analitis aposteriori, dan yang sentetis aposteriori. Pengetahuan apriori pengetahuan yang tidak tergantung pada pengalaman atau yang ada sebelum pengalaman, pengetahuan aposteriori terjadi akibat pengalaman, pengetahuan analitis merupakan hasil analisis, dan pengetahuan sintetis hasil keadaan yang mempersatukan dua hal yang biasanya terpisah. Metode memperoleh pengetahuan intuisionisme setidaknya dalam beberapa bentuk, pengetahuan yang lengkap diperoleh melalui intuisi sebagian saja, yang diberikan oleh analisis. Apa yang diberikan oleh indera hanyalah yang menampak belaka, sebagai lawan dari apa yang diberikan oleh intuisi, yaitu kenyataan. Konsep pengetahuan tentang disebut pengetahuan yang langsung atau pengetahuan intuitif, dan pengetahuan tersebut diperoleh secara langsung. Cara memperoleh pengetahuan melalui metode ilmiah mengikuti prosedur-prosedur tertentu yang sudah pasti, yang digunakan dalam usaha memberi jawaban atas pertanyaan-pertanyaan yang dihadapi seorang ilmuwan (Kattsoff, 2004: 131-144). Selain lima metode cara memperoleh pengatahauan yang telah 
disebutkan oleh Kattsoff, ada satu metode lagi yaitu berdasarkan wahyu. Wahyu adalah berita yang disampaikan oleh Tuhan kepada intelektual manusia (Pranarka, 1987:87-88). Hal itu sesuai dengan apa yang disampaikan oleh Wiramiharja (2007:91) bahwa salah satu kebenaran ilmu adalah wahyu, yaitu ilmu Tuhan yang nilai kebenarannya bersifat mutlak karena Tuhan bersifat maha sempurna.

Hasil penelitian tentang epistemologi Serat Centhini terdiri dari berbagai pengetahuan Jawa, sebagaimana diungkapkan dalam pendahuluan jilid-1 bahwa Serat Centhini merupakan baboning sanggyaning pangawikan Jawi (induk semua pengetahuan Jawa). Macam pengetahuan Jawa dalam Serat Centhini sebagaimana dinyatakan oleh Darusuprapto (1991:3) dalam saduran Serat Centhini jilid satu, antara lain mengenai hal ikwal yang bertalian dengan agama, mengenai beraneka ilmu: kebatinan, kekebalan, perkerisan, perumahan, dan pertanian; berbagai kesenian: kesusasteraan, karawitan, dan tari; bermacam primbon: perhitungan baik buruk hari atau waktu berjampi-jampi; berbagai jenis masakan makanan; adat istiadat dan cerita yang bertalian dengan peninggalan bangunan kuna setempat, dan sebagainya. Ki Sumidi (dalam Kamajaya, 1996:11-12) menyebutkan ada 28 golongan pengetahuan Jawa, yaitu: sejarah, ramalan, etika, kepurbakalaan, kesosialan, bahasa dan sastra, agama Islam, agama budha, agama kadewan, filsafat, keajaiban, kejiwaan, ilmu senjata-wesi aji, ilmu kuda, ilmu mengendarai kuda, asmara, kesenian, ilmu bangunan rumah, obatobatan dan penyakit, ilmu bumi, hewan, tumbuh-tumbuhan, pertanian, primbon, kesenangan dan pertunjukan, tata cara, pendidikan, tipe manusia, magi hitam, dan campuran.

Sumber pengetahuan Jawa yang terdapat dalam Serat Centhini berasal dari pengetahuan inderawi atau panca indera dan pengetahuan otoritas. Pengetahuan yang berasal dari pengalaman inderawi merupakan sumber pengetahuan yang berupa alat-alat untuk menangkap obyek dari luar diri manusia melalui kekuatan indra. Pengetahuan dalam Serat Centhini yang berasal dari kekuatan indera misalnya saat perjalanan Jayengresmi di wilayah Kuwu. Jayengresmi behenti di tepi padang berbentuk persegi dan memilih tanah yang keras, sebab tanah yang empuk tidak dapat diinjak. Jayengresmi takjub melihat di tengah Bedhug mengembung seperti gelembung. Kembungnya tinggi sekali. Begitu tampak segera pecah berdebur keras bunyinya, terdengar seperti meriam mengeluarkan asap putih. Setelah meletus bagian bawah mengembang lagi seperti semula (Darusuprapto, 1991: 75). Pengetahuan tentang bledhuk kuwu ini berasal dari kekuatan indera pendengaran dan penglihatan.

Pengetahuan yang berasal dari otoritas adalah pengetahuan yang berasal dari kekuasaan yang sah yang dimiliki oleh seseorang dan diakui oleh kelompoknya. Dalam Serat Centhini, sebagaian besar pengetahuan diperoleh melalui otoritas, terutama otoritas kyai dan wali, misalnya pengetahuan yang berasal dari otoritas Seh Amongraga sebagai wali yaitu saat mengajarkan ilmu kesempurnaan hidup kepada istrinya Niken Tambangraras, kepada kedua abdinya Jamal dan Jamil, kepada kedua adik Tambangraras yaitu Jayengraga dan Jayengwresthi, kepada santri-santri di Wanamarta, kepada orangorang yang dijumpai saat berkelana, dan sebagainya. Demikian juga, pengetahuan yang barasal dari Ki Ageng Karang, yang merupakan seorang kyai yang mengajarkan ilmu kesempurnaan hidup kepada para santri, termasuk Seh Amongraga sendiri sebagai santri Ki Ageng Karang. Ki Bayi Panurta dengan otoritasnya sebagai kyai juga mengajarkan ilmu kepada santri-santrinya di Wanamarta.

Metode pengetahuan dalam Serat Centhini terdiri atas metode empirisme, 
rasionalisme, dan wahyu. Ilmu pengetahuan yang diperoleh berdasarkan metode empirisme misalnya wejangan Wasi Kawiswara di Gunung Panegaran kepada Jayengresmi (sebelum Jayengresmi berganti nama Seh Amongraga) tentang astabrata. Astabrata, watak delapan dewa, yang tertulis dalam kitab Ramayana. Watak delapan dewa itu adalah pertama, Hyang Indra pekerjaannya menghujankan segala wangi-wangian, menyebabkan seluruh dunia sedap dipandang, penuh rasa keindahan, merasuki hati dan dada, membangkitkan rasa rindu serta hasrat mengheningkan cipta. Kedua, Dewa Yama yang bertugas menghukum yang tidak benar, agar layu merana ibarat mati, penjahat sampah dunia, sekalipun berjumlah banyak gerombolan berani menginjak, dihukum hukuman mati. Ketiga, Dewa Surya, menghisap air tidak kelihatan tenang perlahan-lahan, pembicaraanya tidak memgerikan, bersih tiada henti, teratur rapi, senatiasa berhati-hati. Keempat, Dewa Candra masuk mengasapi bumi, nampak halus lagi lembut, senyumnya manis ibarat titik air utama, indah bagi para resi. Kelima, Dewa Bayu, mengintai segala perbuatan, pikiran rakyat segala tutur katanya diketahui, termasyur, pandai, berguna bagi kehidupan sehari-hari. Keenam, Dewa Kuwera menyediakan makan yang nikmat, menghiasi pakaian emas, kuat sekali masuk menguasai rakyat, mempercayai yang dipercaya, tidak mengganggu dan tidak mengusik. Ketujuh, Dewa Baruna, menggunakan senjata untuk mengikat semua yang berbuat jahat, dijelajahi dengan giat dicari kemana-mana, kemudian ditangkap. Kedelapan, Dewa Brama, dengan seksama, berani dengan siapa saja seperti singa, yang diserang sirna, menyala merata semua terkena api. Hal-hal yang dilakukan oleh delapan dewa ini agar digunakan sebagai pedoman hidup. Ajaran agar mencontoh delapan dewa merupakan pengetahuan empirik yang telah dilakukan para pemimpin masa lalu.
Ilmu pengetahuan yang diperoleh dengan metode rasionalisme misalnya wejangan Wasi Kawiswara di Gunung Panegaran kepada Jayengresmi pada jilid I pupuh 37 (sebelum Jayengresmi berganti nama Seh Amongraga), yaitu tentang hidup bermasyarakat agar disenangi sesama. Isi wejangan Wasi Kawiswara, antara lain pokok utama dalam hidup agar selalu menyenangkan hati orang lain, tenggang rasa, sopan santun, senantiasa mengingat hakikat sebagai makhluk Tuhan, menyayangi sesama hidup, hidup prihatin dengan tetap memperhatikan hidup bermasyarakat, belum dapat dikatakan telah sampai pada tujuan manakala orang belum dapat dengan sabar menerima sebab musabab Tuhan menetapkan petunjuk, memperbanyak tafakur, lihatlah kenyataan hidup dan apabila berhasil jangan lupa diri, dan sebagainya semuanya berupa petunjuk bagaimana hidup bermasyarakat. Semua petunjuk hidup bermasyarakat ini disampaikan sesuai dengan prinsip rasionalitas, orang agar dihargai dirinya harus menghargai orang lain, orang agar dapat hidup bermasyarakat harus mengikuti tata aturan yang berlaku di masyarakat, dan sebagainya.

Ilmu pengetahuan yang diperoleh berdasarkan metode wahyu misalnya Seh Amongraga memberi wejangan kepada Jayengwesthi dan Jayengraga, putera Ki Bayi Panurta di Wanamarta, tertulis pada jilid VI pupuh 352. Seh Amongraga menjelaskan tentang syariat nabi, Nabi Muhammad SAW yaiu dalil dalam Alquran, Hadis Qudsi, Ijma, Kiyas, dan Khusus. Agar dalam menyembah Hyang Widi harus kuat memegang dalil, yang utama: syariat, tarekat, hakikat, dan makrifat. Isi syariat adalah tempatnya orang yang pantang segala ria, berguna bila diberi rezeki. Ilmu hakikat itu jika meninggalkan syarak akan dijauhi dan hidupnya terlunta-lunta, disia-siakan, tidak disukai pada masanya. Pada masanya ada dua 
hal, yang pertama zaman ngam dan zaman ekas. Kalau zaman mukmin engam harus menghafalkan dalil serta arti kitab, harus faham menjalani mangunah, itulah sebabnya harus hafal dalil hadis, serta yang harus dijalani tidak boleh berubah, senang puasa, sembahyang, dan mengaji. Itu wahyunya orang jamhur 'pandai ilmu' menjadi landasan ulama mupid 'utama'. Zaman engan-engan yang utama mendapat wahyu suci, permatanya manusia engam dijemput dengan anugerah yang adil. Adapun dalil dan madelul, agar tirainya semakin tebal. Tafakur pada Hyang Suksma, agar menjadi taat dalam berbakti. Kewajiban rasul ada tiga, yaitu sidik, amanat, dan tablik. Sidik artinya benar, amanat artinya terpercaya, tablik artinya menyampaikan. Mustahidnya rasul ada tiga, yaitu khidib, khianat, dan khitman. Khidib artinya tidak tenang, khianat artinya berbohong, khitman artinya menyembunyikan. Itu semua hendaknya selalu diingat pada waktunya siang dan malam.

\section{Aksiologi Serat Centhini}

Aksiologi adalah ilmu pengetahuan yang menyelidiki hakikat nilai, yang umumnya ditinjau dari sudut kefilsafatan (Kattsoff, 2004: 319). Dalam definisi yang lain, Mudhofir (2001:45) menjelaskan bahwa aksiologi dari kata Yunani axios yang berarti bernilai, berharga dan logos berarti kajian tentang. Analisis atas nilainilai untuk menentukan makna, ciri, asal mula, corak, ukuran, dan kedudukan epistemologinya. Wiramiharja (2007:155) menjelaskan aksiologi mempunyai kaitan dengan axia yang berarti nilai atau berharga. Aksiologi dapat diartikan sebagai wacana filosofis yang membicarakan nilai dan penilaian. Aksiologi digunakan terutama sebagai teori umum mengenai nilai.

Hakikat nilai dapat dilihat dari tiga macam pendekatan aksiologi, yaitu subjektivitas, objektivitias logis, dan objektivitas metafisik. Pendekatan subjektivitas menganggap nilai sepenuhnya berhakikat subjektif. Dilihat dari sudut pandang ini nilai-nilai merupakan reaksi-reaksi yang diberikan oleh manusia sebagai pelaku dan keberadaannya tergantung pada pengalaman mereka. Pendekatan objektivitas logis memandang nilai-nilai merupakan kenyataan-kenyataan ditinjau dari segi ontologi, namun tidak terdapat dalam ruang dan waktu. Nilai-nilai tersebut merupakan esensi-esensi logis dan dapat diketahui melalui akal. Pendekatan objektivitas metafisik memandang bahwa nikai-nilai merupakan unsur-unsur objektif yang menyusun kenyataan (Kattsoff, 2004:323).

Menurut Scheler, nilai merupakan suatu kualitas yang tidak tergantung pada pembawanya, merupakan kualitas apriori, yang telah dapat dirasakan manusia tanpa melalui pengalaman inderawi terlebih dahulu, tidak tergantung hanya pada objek yang ada di dunia ini, misalnya lukisan, tindakan manusia, dan sebagainya, juga tidak tergantung pada reaksi terhadap kualitas tersebut. Misalnya, meskipun pembunuh tidak pernah dinyatakan sebagai jahat, namun akan tetap sebagai jahat, dan meskipun yang baik tidak dimengerti sebagai baik, namun tetap merupakan yang baik (Scheler, ditulis oleh Wahana, 2004: 51). Semua nilai berada dalam dua kelompok, yaitu nilai yang positif dan nilai yang negatif. Nilai positif merupakan suatu yang harus ada dan berwujud dalam realitas kehidupan, sedangkan nilai negatif harus tidak ada dan tidak berwujud dalam kehidupan. Sesuatu itu ada sebagai yang secara positif harus ada dan harus berwujud dalam realitas kehidupan adalah benar, sedang sesuatu itu ada sebagai harus tidak ada dan harus tidak berwujud dalam realitas kehidupan adalah salah. Segala ketiadaan yang harus ada dan harus terwujud dalam kehidupan adalah salah, sedangkan segala tindakan dari yang harus tidak ada dan tidak terwujud dalam realitas kehidupan adalah 
benar (Scheler, ditulis oleh Wahana, 2004: 55). Pada bagian lain, Wahana (2004:56) menyebutkan pengertian nilai dari yang absolut dan relatif. Menurut pengertian yang absolut, nilai kebaikan adalah nilai yang tampak pada tindakan mewujudkan nilai yang tertinggi dan nilai kejahatan adalah nilai yang tampak pada tindakan mewujudkan nilai yang terendah. Menurut pengertian relatif, kebaikan moral adalah tindakan mewujudkan nilai, yang sesuai dengan isi nilai yang dimaksud, yaitu setuju dengan nilai yang dinilai lehih tinggi dan tidak setuju dengan nilai yang berada di tingkatan lebih rendah, dan kejahatan moral adalah tindakan yang tidak sesuai dengan isi nilai yang dimaksudkan, yaitu tidak setuju dengan nilai yang lebih tinggi dan setuju dengan nilai yang lebih rendah.

Scheler menyebutkan hierarki nilai dari tingkat lebih tinggi menurun ke tingkat lebih rendah yang bersifat apriori. Hierarki ini tidak dapat direduksikan secara empiris, tetapi terungkap melalui tindakan preferensi. Tingkatan nilai merupakan hal yang keberadaannya memang sudah demikian berdasarkan hakikatnya, dan itu dapat dirasakan melalui preferensi. Tindakan preferensi merupakan tindakan mengunggulkan atau mengutamakan yang diwujudkan tanpa adanya kecenderungan pemilihan atau keinginan. Hierarki terdiri atas empat tingkat, yaitu (1) nilai kesenangan, (2) nilai vitalitas atau kehidupan, (d) nilai spiritual, dan (4) nilai kesucian dan keprofanan (Scheler, ditulis oleh Wahana, 2004: 59-62).

Serat Centhini bermuatan nilai yang tinggi sebagaimana digambarkan oleh Kamajaya (1996: 1-2), yang menyatakan bahwa Serat Centhini berisi segala sesuatu meliputi kehidupan orang Jawa lahir dan batin, filsafat, kebatinan, agama, hingga Ketuhanan yang rumit, mencakup tradisi, kekayaan alam, adat kebiasaan, kepercayaan, kesenian hingga persoalan seks. Pengembaraan Seh Amongraga dari satu ke tempat ke tempat lain, setelah mengalamai masa pendewasaan dengan berguru kepada orang-orang bijak yang dijumpainya, terutama ayah angkatnya Ki Ageng Karang, yang telah memberi wejangan segala ilmu lahir dan batin, Seh Amongraga memberi wejangan kepada orang-orang yang dijumpai dalam pengembaraannya, terutama pada keluarga Ki Bayi Panurta, yaitu keluarga istri Seh Amongraga Niken Tambangraras di Wanamarta. Setelah dari berguru Ki Ageng Karang, yang kemudian diangkat sebagai anak, oleh Ki Ageng Karang, Seh Amongraga diminta menuju Wanamarta tempat kediaman Ki Bayi Panurta yang telah menjadi guru para bupati di wilayah timur. Di Wanamarta ini diceriterakan panjang lebar pada jilid-5, jilid-6, dan jilid-7, peran Seh Amongraga sebagai seh mengajarkan ilmu agama Islam. Kalau dilihat dari hierarki nilai sebagaimana yang disampaikan Scheler, apa yang dilakukan Seh Amongraga banyak menyampaikan nilai-nilai kebaikan berupa nilai kesucian dengan menjauhkan nilainilai negatif dan nilai kejahatan. Sebagai contoh, pada buku jilid-5, ketika tinggal di Wanamarta, Ki Bayi Panurta diwejang olerh Seh Amongraga tentang kegaiban Tuhan hingga terang benderang hatinya, faham segala alam: kamil, missal, ajzan, dan alam arwah. sampai Ki Bayi merasa terungguli ilmu Seh Amongraga. Seh Amongraga pun berusaha menyampaikan nilai-nilai yang dilarang oleh agama, yang oleh Scheler disebut sebagai nilai negatif dan nilai kejahatan. Ketika akan dinikahkan dengan Niken Tambangraras, Seh Amongraga mengajukan syarat agar perkawinan dilaksanakan sesuai dengan syariat agama Islam dengan menjauhkan kemaksiatan. Walaupun dalam kenyataannya masih menghadapi tantangan, karena ketika upacara ngundhuh pengantin di rumah Jayeng Wresthi yang disambut dengan singir dan kendhuri, Seh Amongraga mengajak sanak keluar- 
ganya ke surau dulu untuk melaksanakan sholat, berzikir, dan memberi wejangan tentang salat fardu dan aneka salat sunah, Jayengraga (kakak Niken Tambnngraras) masih berbuat serong dengan ronggeng Senu, karena istrinya sedang datang bulan. Kejadian ini menggambarkan apa yang terjadi di masyarakat saat itu, masih beratnya menyebarkan agama Islam di kalangan masyarakat.

Jika dilihat dari hierarki nilai Scheler, empat tingkatan nilai, mulai dari nilai kesenangan, nilai vitalitas atau kehidupan, nilai spiritual, sampai nilai kesucian, semuanya ada dalam Serat Centhini, hanya porsinya berbeda-beda. Nilai kesenangan dapat dilihat pada bentuk karya Serat Centhini itu sendiri berupa tembang agar tidak menjemukan, tetapi menyenangkan pendengar (Darusuprapto, 1991:1). Nilai vitalitas atau kehidupan dapat dilihat pada sebagian ajaran Seh Amongraga yang berisi ajaran tentang hidup di dunia dan akhirat, yang dikenal sebagai ilmu kesempurnaan hidup. Nilai spiritual dan kesucian merupakan nilai yang mendominasi dalam Serat Centhini. Apa yang diwejangkan oleh Seh Amongraga sebagian terbesar persoalan spiritual dan kesucian, bahkan sampai akhir hayatnya, Seh Amongraga meninggal dengan tujuan untuk mensucikan diri dengan cara muksa.

\section{SIMPULAN}

Sebagai penutup dapat disimpulkan sebagai berikut. Pertama, nilai filosofi Jawa dalam Serat Centhini tergambar pada kandungan budaya dan filsafat Jawa yang menggambarkan keadaan masyarakat Jawa saat Serat Centhini ditulis. Filosofi Jawa dalam Serat Centhini tercermin dalam nilai kesempurnaan hidup (ngudi kasampurnan) dan filsafat asal dan arahnya yang ada (sangkan paraning dumadi). Kesempurnaan hidup digambarkan bahwa manusia mencurahkan seluruh eksistensinya, baik jasmani maupun rohani, untuk mencapai tujuan hidup. Filsafat asal dan arahnya yang ada digambarkan oleh ulah daya hidup manusia yang bergerak menuju dan bersatu dalam kesempurnaan. Kedua, filosofi Serat Centhini tercermin dalam landasan ontologis, epistimologis, dan aksiologis. Ontologi dalam Serat Centhini berangkat dari kenyataan yang sungguh-sungguh ada, yaitu tentang segala pengetahuan Jawa yang dapat digunakan sebagai induk semua pengetahuan Jawa, yang merupakan realitas kehidupan masyarakat pada saat Serat Centhini itu ditulis. Pengetahuan Jawa yang ada dalam Serat Centhini, mulai dari sejarah, etika, agama, sampai dengan filsafat, yang bersumber dari pengetahuan inderawi dan otoritas merupakan cerminan dari landasan epistimologis. Landasan aksiologis yang tercermin dalam kesempurnaan hidup serta asal dan arahnya yang ada menjadi pedoman kehidupan orang Jawa lahir dan batin.

\section{UCAPAN TERIMA KASIH}

Artikel ini ditulis dengan mengolah dari sebagian hasil penelitian disertasi berjudul "Filsafat Moral dalam Serat Centhini Melalui Tokoh Seh Amongraga, Sumbangannya bagi Pendidikan Karakter". Oleh karena itu, disampaikan terima kasih kepada LPPM UNY yang telah membantu dana penelitian untuk percepatan disertasi dan Prof. Dr. Joko Siswanto dan Prof. Dr. Ahmad Dardiri, M.Hum selaku selalu konsultan dan promotor.

\section{DAFTAR PUSTAKA}

Arif, Syaiful. 2010. Refilosofi Kebudayaan. Yogyakarta: Ar-ruzz Media

Bakker, Anton. 1992. Ontologi Metafisika Umum: Filsafat Pengada dan Dasar-dasar Kenyataan. Yogyakarta: Kanisius.

Ciptoprawiro, Abdullah. 1986. Filsafat Jawa. Jakarta: Balai Pustaka

Darusuprapto (Penyunting). 1991/1992. Centhini Tambangraras-Amongraga Jilid I. Jakarta: Balai Pustaka. 
Driyarkara. 2006. Karya Lengkap Driyarkara: Esai-esai Filsafat Pemikir yang Terlibat Penuh dalam Perjuangan Bangsanya (disunting oleh Sudiarja, Budi Subanar, Sunardi, dan Sarkim). Jakarta: PT Gramedia Pustaka Utama.

Gallagher, Kenneth T. 1994. Epistemologi: Filsafat Pengetahuan, Saduran dari The Phillosophy of Knowledge oleh Hardono Hadi. Yogyakarta: Kanisius.

Hardono, Hadi. 1996. Epistimologi: Filsafat Pengetahuan. Yogyakarta: Kanisius.

Kamajaya, Karkana. 1995. Serat Centhini Latin Jilid I, V, VI, VII. Yogyakarta: UP Indonesia.

Kamajaya, Karkana. 1996. “Serat Centhini sebagai Sumber Inspirasi Pengembangan Sastra Jawa". Semarang: Kongres Bahasa Jawa II.

Kamajaya, Karkana. 2007. “Manusia Jawa dan Kebudayaannya dalam Negara Kesatuan RI" dalam Menggali Filsafat dan Budaya Jawa. Surabaya: Lembaga Javanologi Surabaya.

Kattsoff, Louis O. 2004. Pengantar Filsafat, terjemahan dari Elements of Philosophy oleh Soejono Soemargono. Yogyakarta: Tiara Wacana.

Koentjaraningrat, 1979. Pengantar Ilmu Antropologi. Jakarta: Aksara Baru.

Koesnoe, Moh, 2007. “Sangkan Paraning Dumadi: sebagai Filsafat dan Ngelmu" dalam Menggali Filsafat dan Budaya Jawa. Surabaya: Lembaga Javanologi Surabaya.

Kusbandriyo, Bambang. 2007. "Pokokpokok Filsafat Jawa" dalam Menggali Filsafat dan Budaya Jawa. Surabaya: Lembaga Javanologi Surabaya.

Kusumohamidjojo, Budiono. 2009. Filsafat Kebudayaan. Yogyakarta: Jalasutra.
Marsono, (penyunting), 2005. Centhini Tambangraras-Amongraga V, VI, VII. Yogyakarta: Gadjah Mada University Press.

Mudhofir, Ali. 1996. Kamus Teori dan Aliran dalam Filsafat dan Teologi. Yogyakarta: Gadjah Mada University Press.

Mudhofir, Ali. 2001. Kamus Istilah Filsafat dan Ilmu. Yogyakarta: Gadjah Mada University Press.

Nasroen, M. 1976. Falsafah dan Cara Berfalsafah. Jakarta: Bulan Bintang.

Peursen, C.A. van. 1988. Strategi Kebudayaan, diterjemahkan dari Culture in Stroom-vernelling oleh Dick Hartoko. Yogyakarta: Kanisius

Poerbacaraka dan Tarjan Hadijaya. 1957. Kepustakaan Jawa. Jakarta: Djambatan

Pranarka dan Bakker A (redaktur). 1979. "Epistemologi Kebudayaan dan Pendidikan". Yogyakarta: Simposium Filsafat tentang Epistemologi.

Suseno, Frans M. 1992. Filsafat sebagai Ilmu Kritis. Yogyakarta: Kanisius

Suseno, Frans M. 2005. Pijar-pijar Filsafat. Yogyakarta: Kanisius

Sutrisno, Mudji. 2008. Filsafat Kebudayaan: Ikhtisar Sebuah Teks. Jakarta: Hujan Kabisat.

Wahana, Paulus. 2004. Nilai Etika Aksiologis Max Scheler. Yogyakarta: Kanisius

Wellek, Rene dan Warren, Austin, 1989. Teori Kesusasteraan (terjemahan dari Theory of Literature oleh Melani Budianta). Jakarta: Gramedia.

Wiramihardja, A., Sutarjo. 2007. Pengantar Filsafat (Sistematika Filsafat, Sejarah Filsafat, Logika dan Filsafat Ilmu 'Epistemologi', Metafisika dan Filsafat Manusia, dan Aksiologi). Bandung: Aditama. 